\title{
Preferences of Rusa timorensis to Grasses and Their Body Morphometry and Velvet Antler Characteristics
}

\author{
M. Sudibyo ${ }^{\mathrm{a}, \mathrm{b}, *}$, Y. Santosa ${ }^{\mathrm{b}}$, B. Masy'ud ${ }^{\mathrm{c}, \#}$, \& T. Toharmat ${ }^{\mathrm{d}, \#}$ \\ ${ }^{a}$ Major Program of Tropical Biodiversity Conservation, Graduate School, Bogor Agricultural University \\ ${ }^{b}$ Faculty of Mathematics and Natural Sciences, State University of Medan \\ Jln. Willem Iskandar Pasar V Medan Estate, Medan 20221, Indonesia \\ 'Faculty of Forestry, Bogor Agricultural University \\ dFaculty of Animal Science, Bogor Agricultural University \\ ${ }^{*}$ Kampus IPB Darmaga, Bogor 16680, West Java, Indonesia \\ (Received 17-06-2013; Reviewed 22-07-2013; Accepted 13-09-2013)
}

\begin{abstract}
Timor deer (Rusa timorensis) is a wild native animal to Indonesia. The stags produce a high economic value of velvet antler (VA). This study was designed to evaluate the feed preference, nutrient consumption, age and morphometric of deer in relation to their velvet antler product (weigth and length) and quality (mineral and amino acids). Five stags with three ages classes were offered 3 combinations of 4 grasses in a captive area. Grasses were offered for 3 periods of 12 consecutive days during velvet antler growth period. Velvet antlers were harvested at 36 days old and analysed for their chemical content. The result showed that Timor deer had different preference to the grasses offered. Deer had a high preference on the combination of Pennisetum purpureum, Commelina benghalensis, Hierochloe horsfieldii, and Sorghum caudatum. High intake of grasses increased body weight. The regresion equation between the weight or length of velvet antler withage (year) and girth size $(\mathrm{cm})$ were: $Y$ (velvet antler weight) $=0.43+0.03$ (age), $\mathrm{r}^{2}=0.99, P<0.05$, and $Y$ (length of velvet antler) $=5.7+$ 0.31 (girth size), $\mathrm{r}^{2}=0.99, \mathrm{P}<0.05$. Aspartic acid, glutamic acid, and proline content of velvel antler were high in the older deer. The older deer having high girth size had the higher quality of velvet antler.
\end{abstract}

Key words: antler characteristic, deer, feed preference, velvet antler

\section{ABSTRAK}

Rusa Timor (Rusa timorensis) adalah satwa asli Indonesia. Rusa jantan dapat menghasilkan ranggah muda yang bernilai ekonomi tinggi. Penelitian ini bertujuan mendapatkan kaitan kesukaan rusa terhadap pakan, konsumsi nutrien, umur dan morfometri rusa terhadap berat dan panjang serta kualitas mineral dan asam amino ranggah muda yang dihasilkan. Lima rusa jantan dengan tiga kelas umur diberi 3 kombinasi rumput, masing-masing terdiri atas 4 jenis dari 12 jenis pakan yang disukai di penangkaran. Pemberian pakan dilakukan selama 3 periode masing-masing selama 12 hari selama pertumbuhan ranggah muda. Ranggah muda dipanen setelah berumur 36 hari dan dianalisis kandungan kimianya. Hasil penelitian menunjukkan bahwa Rusa Timor mempunyai preferensi berbeda terhadap rumput yang diberikan. Rusa sangat menyukai kombinasi jenis pakan Pennisetum purpureum, Commelina benghalensis, Hierochloe horsfieldii, dan Sorghum caudatum dengan asupan yang tinggi yang meningkatkan bobot badan. Berat dan panjang ranggah muda dipengaruhi berturut-turut oleh umur (tahun) dan lingkar dada $(\mathrm{cm})$, mengikuti persamaan: $Y$ (berat ranggah muda) $=0,43+$ 0,03 (umur), $\mathrm{r}^{2}=0,99, \mathrm{P}<0,05$; dan $\mathrm{Y}$ (panjang ranggah muda)= 5,7+0,31 (lingkar dada), $\mathrm{r}^{2}=0,99, P<0,05$. Kandungan aspartat, glutamat, dan proline lebih tinggi pada rusa yang lebih tua. Rusa yang berumur lebih tua dan memiliki lingkar dada lebih lebar memiliki produk dan kualitas ranggah muda lebih tinggi.

Kata kunci: karakteristik ranggah, rusa, preferensi pakan, ranggah muda

*Corresponding author:

E-mail: msud16@gmail.com 


\section{INTRODUCTION}

Timor deer (Rusa timorensis de Blainville 1822) is a wild native animal to Indonesia. However, during the least three generations (estimated as a minimum of $15 \mathrm{yr}$ ), deer population decreased by $10 \%$, as a result of hunting activities. It was recorded that in 2008, the population of deer was about 10,000 heads (Hedges at al., 2008). Therefore, IUCN has listed the timor deer in the vulnerable status (Hedges at al., 2008). Rusa has been an genetic resources animal (Pattiselanno, 2003) and has high economic and estetic value (Wirdateti \& Semiadi, 2007). Conservation of Timor deer has been a priority to minimize the reduction of their population. Utilization of velvet antler from the mature stag rather than slauthering them to obtain their meat, is an alternative to conservation effort.

Velvet antler from deer has high concentration in Insulin Like Growth Factor (IGF-1), glycosaminoglycans (GAGs), vitamin A and E, uronic, and sialatic acid (Tuckwell, 2003; Lee et al., 2007). It is high in minerals (Ca, P, Mg, Na, Mn, Fe, and Se) and high in 8 essential amino acids and 15 non-essential amino acids (Kawtikwar, 2000). The velvet antler has been utilized as a component of Chinese medicine (Dradjat, 2000), as an anti aging and to improve the performance of atlets (Tuckwell, 2003; Lee et al., 2007).

Quality of velvet antler is influenced by various factors including, genetic (strain, hibridization, selection), body size, age and harvest time (Gibbs, 2006), and development stage (Jeon et al., 2011). Chemical composition of velvet antler indicates the amount and quality of feed that was comsumed by the stag. Protein, $\mathrm{Na}, \mathrm{K}$ and $\mathrm{Mg}$ contents (Estevez et al., 2008) and growth of velvet antler of velvet antler (Kilgo \& Labisky, 1995) were affected by protein, $\mathrm{Ca}, \mathrm{P}$, and $\mathrm{Mg}$ content of feed.

Length of yearly velvet in red deers (Cervus elaphus) is an indicator of the availability and quality of their feed as well as population condition (Scmidt et al., 2001; Jeon et al., 2006a). Nutritional deficiency resulted in negative impact on pedicle development in fawns and the growth of antlers in all age classes (Demarais, 2002). Velvet size indicates the age, health status and genetic of stag. Timor deer had 3 antler growth period, including casting period of $16.25 \pm 0.88 \mathrm{~d}$, velvet antler period of $155.75 \pm 7.11 \mathrm{~d}$, and hard antler period of $207.25 \pm 2.75$ $\mathrm{d}$, and the total of yearly antler period period was 379.25 \pm 2.75 d (Handarini, 2006). Velvet antler for medicinal purpose was hasversted before day 60 (Dradjat, 2000). Nutrient intake contributed to the weight gain of the deer. Stewart et al. (2000) indicated that the ratio of velvet antler and body weight had positive correlation with age. Nutrient sufficiency and good population management result in healthy stag and high quality of velvet antler. The objectives of the present study were to evaluate the preference of deer on type of feed, nutrient intake, age and morphometric factors affecting weight, length and nutrients content of velvet antler.

\section{MATERIALS AND METHODS}

\section{Time and Location}

The preference of Timor deer on 20 type grasses was evaluated in the period of January 2011 to April 2011. In the period of Januari 2012 to April 2012, the most prefered of 12 grasses was combined randomly into 3 grass based diets composed of 4 type of grasses. The diets were offered to 5 deers for 3 consecutive $12 \mathrm{~d}$ periods in a captive area of the Conservation and Rehabilitation Center, Dramaga Forest Research. Harvest period of the velvet antlers wich have nutricitical compounds in Timor deer was 30-60 d. Therefore the feed preference trial for 20 grasses in the period of velvet antlers growth was conducted in 2011. The feed preference trial was conducted to evaluate and confirm the preference of the deer to 12 most prefered grasses. The trial was followed by the evaluation on physical and chemical charateristic of harvested velvet antler.

\section{Data Collection and Analysis}

Study of feed preference of timor deer to the most avalaible grasses in the region (20 type of grasses) was conducted for $30 \mathrm{~d}$ period. Four type of grasses were selected randomly and offered to 5 deers for 6 consecutive days. Deer were kept in individual cages and offered a similar combinatoion of grasses. Each type of grass was offered $1 \mathrm{~kg}$ in the morning and $1.25 \mathrm{~kg}$ in the afternoon, every day in four separate throughts, to allow the deer choose the grasss freely. The preference of deer on the grasses was based on the feed selection behavior with score 1 to 4 . The most selected grasses eaten by the deer was scored 1 . The feed selection behavior was recorded in the interval period of $10 \mathrm{~min}$ for $60 \mathrm{~min}$. The weight of each grass consumed by the deer was recorded daily.

Five stags at the stage of velvet antler were used in the study. Three $3 \mathrm{yr}$ old stags had body weight of 62.65 , $48.73,55.52 \mathrm{~kg}$; and one $6 \mathrm{yr}$ old stag had body weight of $62.40 \mathrm{~kg}$ and one of $9 \mathrm{yr}$ old stag had body weight of $60.60 \mathrm{~kg}$. The stags were kept in $1.5 \times 2 \mathrm{~m}^{2}$ individual cages.

In the first period of the study, 12 kinds of highly prefered grasses by the timor deer were rendomly choosen as the component of three rations. Ration A was composed of Sorghum candatum, Hierochloe horsfieldii, Commelina benghalensis and Pennisetum purpureum; ration B was composed of Scrophia sp., Axonopus compresus, Caliandra calothyrsus and Leersia hexandra; ration $\mathrm{C}$ was composed of Cynodon dactylon, Panicum montanum, Setaria palmifolia and Coix lacryma.

Grasses in each ration were offered individualy to five experimental deers in separate feed throught in a cafetaria system (Babayemi et al., 2006; Farid et al., 2006; Rodriguez et al., 2007). Each grass was offered $2.25 \mathrm{~kg}$ at 07.00 and 16.00. Ration A was offered for the first $12 \mathrm{~d}$ followed by $12 \mathrm{~d}$ period of feeding ration $\mathrm{B}$ and the last $12 \mathrm{~d}$ of feeding ration $\mathrm{C}$. Residual of each grass rejected by the deer, after feeding for $24 \mathrm{~h}$, was weighed separately. Samples of each grass offered and residual feed 
rejected by the deer were collected and dried daily and then the samples were mixed at the end of the experimental period for chemical analysis.

During the second period of the study, body weight and body conformation including body height and length as well as heart girth of the deer were determined. The body conformation was determined on day 0 and 36. Weighing of the deer was conducted four times on day $0,12,24$, and 36 , before harvesting the velvet antler. Local anestacy using $4 \mathrm{ml}$ lignocain $\mathrm{HCl} 2 \%$ (Wals \& Wilson, 2002) was injected on the right and left side, at three points on pedical part.

A sterile iron saw was used to cut the velvet antlers. An antibiotic of Limoxin 25 was sprayed to cover the base of the velvet after cutting. Velvet antlers obtained were wilted on the updown position. Weight, length, diameter of velvet antlers were determined. Samples of velvet were stored in $4{ }^{\circ} \mathrm{C}$ for $2-3 \mathrm{~d}$ before measurement and chemical analysis. The velvet antlers were dried in an oven at $45^{\circ} \mathrm{C}$ for two periods of 6 hours. The velvet antlers were placed out side the oven for $1-2 \mathrm{~h}$ before the second period of drying. The fine hair of velvet antlers were cleaned by quick burning. Finally the dry velvet antlers were sliched and ground for chemical analysis. Dry matter, ash, ether extract, crude protein, crude fiber, mineral and amino acids contents of the velvet antlers of the deer were determined. Descriptive statistical analysis was applied to determine the factors influencing the weight and chemical composition of the velvet antler.

\section{RESULTS AND DISCUSSION}

\section{Feed Preference}

The type of grasses and their score according to the feed selection behavior are indicated in Table 1. Timor deer prefered to select almost all of the grass type offered during the study. The score varied from 1.62 to 3.80. The preference of the deer to the grass was likely influenced by the physical and chemical characteristic of the grass. The first 12 grasses were the most available grasses in the region and they indicated low score, which mean that thay were prefered by the timor deer.

\section{Feed Intake}

Total dry matter intake and the intake of each grass offered to the Timor deers were shown in Table 2. Timor deer at age of 3-9 yr old having body weight of $59.18 \pm 7.07 \mathrm{~kg}$ had the dry matter intake of $834-1549 \mathrm{~g} / \mathrm{d}$. Type of grass and age of timor deer influenced the total dry matter intake. The deer indicated different preference on grass type. In the present study, the dry matter intake of ration A was higher in all age classes. Timor deer indicated the high intake of $P$. purpureum and $C$. benghalensis, $H$. horsfieldii and S. candatum (Table 2). The preference of the deer on the grass might be influenced by physical caracteristics and nutrients content of the grass (Ceacero et al., 2010). Intake of mixed grass might have supplementary effect among the grass to meet nutrients requirement of the deer, but feeding low palatability grass reduced the total dry matter intake.

Timor deer offered grass had total dry matter intake of $28 \pm 3,24 \pm 1$, and $26 \pm 1(\mathrm{~g} / \mathrm{kg} \mathrm{BW} / \mathrm{d})$, at age of 3,6 , and 9 yr old, respectively. The younger deer indicated high dry matter intake, since they likely need more nutrients for maintenance and their growth. Grass had low energy and protein content, therefore they were able to utilize the ingested nutrients efficiently for their maintenance and their growth.

High dry matter intake of ration A increased body weight by $91 \mathrm{~g} / \mathrm{d}$ in the $12 \mathrm{~d}$ feeding period. On the other hand, the deer indicated reduction in body weight of $1.41 \mathrm{~kg}$ and $0.75 \mathrm{~kg}$ in the period of $12 \mathrm{~d}$ of feeding ration $B$ and $C$, respectively. Increased in body weight could be the result of the increase in energy and protein intake. Afzalani et al. (2008) reported that high energy and protein intake improved the body weight. Combination of different grass with high palatability in the ration might improve the body weight of the deer.

The results indicated that the Timor deer offered grass in a cafetaria system allowed them to choose the grass, increased dry matter intake and improved their body weight. On the other hand, a sufficient ammount of the grass with low palatability might not improve the body weight of the deer, since they had low dry matter intake. Body weight indicated low corelation with velvet

Table 1. Score of the preference of Timor deer on the type of grasses in a captive area

\begin{tabular}{|c|c|c|c|c|c|c|c|}
\hline No & Local name & Scientific name & Score & No & Local name & Scientific name & Score \\
\hline 1 & Hopea & Scrophia sp & 1.62 & 11 & Cacabean & Asystasia spp & 2.64 \\
\hline 2 & Sulanjana & Hierochloe horsfieldii & 2.00 & 12 & Alang-alang & Imperata cylindrica & 2.65 \\
\hline 3 & Sauheun & Setaria palmifolia & 2.02 & 13 & Bayondah & Isachne globosa & 2.65 \\
\hline 4 & Sorgum & Sorghum candatum & 2.27 & 14 & Gewor & Commelina benghalensis & 2.74 \\
\hline 5 & Papadian & Leersia hexandra & 2.28 & 15 & Kaliandra & Caliandra calothyrsus & 2.82 \\
\hline 6 & Setaria & Setaria sphacelata & 2.30 & 16 & Hanjeli & Coix lacryma & 2.88 \\
\hline 7 & Kipait & Axonopus compresus & 2.33 & 17 & Kaw. merah & Cynodon spp & 2.90 \\
\hline 8 & Rumput gajah & Pennisetum purpureum & 2.33 & 18 & Kawatan & Cynodon spp & 3.00 \\
\hline 9 & Aawiyan & Panicum montanum & 2.52 & 19 & Kawatan besar & Cynodon spp & 3.35 \\
\hline 10 & Kacangan & Centrosema pubescens & 2.54 & 20 & Mekania & Mikania micrantha & 3.80 \\
\hline
\end{tabular}


Table 2. Daily dry matter intake of three different age classes and body weight (BW) of the deers in a captive area

\begin{tabular}{|c|c|c|c|c|}
\hline Age class (year) & 3 & 6 & 9 & \\
\hline Body weight (kg) & 55.63 & 62.4 & 60.6 & Mean \\
\hline $\mathrm{n}$ & 3 & 1 & 1 & \\
\hline \multicolumn{5}{|l|}{ Ration $\mathrm{A},(\mathrm{g} / \mathrm{h} / \mathrm{d})$} \\
\hline Sorghum candatum & $328 \pm 9^{d}$ & $332 \pm 2^{b}$ & $331 \pm 4^{\mathrm{c}}$ & $329 \pm \quad 7$ \\
\hline Hierochloe hors fieldii & $361 \pm 21^{\mathrm{c}}$ & $375 \pm \quad 1^{\mathrm{ab}}$ & $376 \pm 1^{b}$ & $367 \pm 18$ \\
\hline Commelina benghalensis & $397 \pm 16^{\mathrm{b}}$ & $402 \pm 21^{\mathrm{a}}$ & $396 \pm 32^{b}$ & $398 \pm 19$ \\
\hline Pennisetum purpureum & $463 \pm 17^{a}$ & $416 \pm 46^{\mathrm{a}}$ & $446 \pm 26^{a}$ & $450 \pm 30$ \\
\hline Mean, $(\mathrm{g} / \mathrm{h} / \mathrm{d})$ & $387 \pm 53$ & $381 \pm 40$ & $387 \pm 47$ & $385 \pm 10$ \\
\hline Total intake, (g/h/d) & $1,549 \pm 42^{\mathrm{A}(\mathrm{A})}$ & $1,526 \pm 56^{\mathrm{A}(\mathrm{A})}$ & $1,549 \pm 45^{\mathrm{A}(\mathrm{A})}$ & $1,424 \pm 62$ \\
\hline$(\mathrm{g} / \mathrm{kg} \mathrm{BW} / \mathrm{d})$ & $28 \pm \quad 3$ & $24 \pm \quad 1$ & $26 \pm \quad 1$ & $27 \pm \quad 3$ \\
\hline \multicolumn{5}{|l|}{ Ration $\mathrm{B},(\mathrm{g} / \mathrm{h} / \mathrm{d})$} \\
\hline Scrophia sp & $176 \pm 19^{b}$ & $195 \pm 4^{a}$ & $198 \pm 0.3^{\mathrm{a}}$ & $184 \pm 18$ \\
\hline Axonopus compresus & $246 \pm 56^{\mathrm{a}}$ & $268 \pm 58^{\mathrm{a}}$ & $272 \pm 32^{\mathrm{a}}$ & $255 \pm 50$ \\
\hline Caliandra calothyrsus & $169 \pm 67^{b}$ & $226 \pm 84^{a}$ & $242 \pm 66^{a}$ & $195 \pm 72$ \\
\hline Leersia hexandra & $243 \pm 45^{a}$ & $287 \pm 47^{a}$ & $267 \pm 52^{a}$ & $257 \pm 47$ \\
\hline Mean, $(\mathrm{g} / \mathrm{h} / \mathrm{d})$ & $209 \pm 32$ & $244 \pm 37$ & $245 \pm 37$ & $223 \pm 34$ \\
\hline Total intake, (g/h/d) & $834 \pm 122^{\mathrm{B}(\mathrm{B})}$ & $976 \pm 185^{\mathrm{A}(\mathrm{B})}$ & $979 \pm 144^{\mathrm{A}(\mathrm{B})}$ & $891 \pm 148$ \\
\hline$(\mathrm{g} / \mathrm{kg} \mathrm{BW} / \mathrm{d})$ & $15 \pm 3$ & $16 \pm 3$ & $16 \pm 3$ & $16 \pm 3$ \\
\hline \multicolumn{5}{|l|}{ Ration $C_{1}(\mathrm{~g} / \mathrm{h} / \mathrm{d})$} \\
\hline Cynodon dactylon & $249 \pm 31^{\mathrm{ab}}$ & $259 \pm 48^{\mathrm{bc}}$ & $245 \pm 59^{b}$ & $250 \pm 37$ \\
\hline Panicum montanum & $202 \pm 28^{b}$ & $227 \pm 16^{c}$ & $234 \pm 7^{b}$ & $213 \pm 27$ \\
\hline Setaria palmifolia & $251 \pm 47^{\mathrm{ab}}$ & $308 \pm 1^{b}$ & $308 \pm 34^{b}$ & $273 \pm 48$ \\
\hline Coix lacryma & $291 \pm 141^{\mathrm{a}}$ & $454 \pm 59^{a}$ & $421 \pm 65^{\mathrm{a}}$ & $350 \pm 135$ \\
\hline Mean, (g/h/d) & $248 \pm 81$ & $312 \pm 87$ & $302 \pm 88$ & $287 \pm 47$ \\
\hline Total intake, (g/h/d) & $992 \pm 211^{\mathrm{B}(\mathrm{B})}$ & $1,248 \pm 98^{\mathrm{A}(\mathrm{B})}$ & $1,208 \pm 149^{\mathrm{A}(\mathrm{B})}$ & $1,087 \pm 211$ \\
\hline$(\mathrm{g} / \mathrm{kg} \mathrm{BW} / \mathrm{d})$ & $18 \pm \quad 4$ & $20 \pm \quad 2$ & $20 \pm 3$ & $19 \pm \quad 4$ \\
\hline
\end{tabular}

Note: Means in the same column and diet with different supperscript differ significantly ( $<<0.05)$; Means in the same row with different capital supperscript differ significantly $(\mathrm{P}<0.05)$; Total value in the same column with different capital supperscript parenthesis differ significantly $(\mathrm{P}<0.05)$.

weight (Drajat, 2000). However, there was a high correlation between the ratio of velvet to body weight with the age of deer (Stewart et al., 2000). Therefore, increasing body weight of the deer was important to obtain the high weight of velvet antler.

\section{Nutrients Intake}

Means of daily nutrients intake of three different age classes of Timor deers in a captive area are indicated in Table 3. There was no different nutrient intake of ration $\mathrm{A}, \mathrm{B}$ and $\mathrm{C}$ among the deer in three different classes. There was a tendency that the younger deer had high dry matter intake. Luna et al. (2013) found that deers with smaller body weight were likely able to select and consume a higher quality diet.

Rations B and C supplied lower protein to the deer. However, the deer in the same class indicated different nutrients intake. The pattern of nutrients intake of ration A, B, and C were similar with that of dry matter intake. Each grass as the component of a diet contributed to the total of ingested nutrients, but the lower palability of the grass the lower the dry matter and nutrients intake contributing to the total of ingested dry matter and nutrients from the ration. High nutrient content grass had high dry matter intake. The deer indicated difference preference to the grass offered in three different rations, and therefore resulted in the variation of the ingested nutrient. P. purpureum indicated the highest palatability and dry matter intake in ration $\mathrm{A}$, on the other hand $H$. horsfieldii had the lowest palability and dry matter intake.

The reduction of body weight during feeding rations $B$ and $C$ was likely as a result of low dry matter and protein intake. Altough the increased in body weight during feeding ration A was partly associated with convensatory growth, but the protein intake at 32 $\mathrm{g} / \mathrm{d}$ was likely adequate to meet the protein requirement for maintenant and it allowed to increase body weight. Protein sufficiency indicated a significant effect on the growth velvet antler, although the protein intake had no effect on nutrient composition of the velvet antler of spotted deer (Jeon et al., 2006b). The growth of velvet antler was reduced by low protein intake (Shin et al., 
Table 3. Mean of individual daily nutrients intake of three different age classes of Timor deers in a captive area

\begin{tabular}{|c|c|c|c|c|c|}
\hline Age class, years & 3 & 6 & 9 & \multirow{3}{*}{ Mean } & \multirow{3}{*}{ Signif } \\
\hline Body weight, $\mathrm{kg}$ & 55.63 & 62.4 & 60.6 & & \\
\hline $\mathrm{n}$ & 3 & 1 & 1 & & \\
\hline \multicolumn{6}{|l|}{ Ration A (g/h/d) } \\
\hline Dry matter & $1,549 \pm 212$ & $1,526 \pm 147$ & $1,549 \pm 192$ & $1,544 \pm 188$ & 0.861 \\
\hline Ash & $167 \pm 30$ & $165 \pm 35$ & $167 \pm 32$ & $167 \pm 32$ & 0.924 \\
\hline Crude protein & $207 \pm 30$ & $204 \pm 20$ & $207 \pm 28$ & $207 \pm 27$ & 0.864 \\
\hline Crude fiber & $710 \pm 121$ & $699 \pm 97$ & $710 \pm 120$ & $707 \pm 111$ & 0.886 \\
\hline Ether extract & $23 \pm 17$ & $23 \pm 19$ & $23 \pm 19$ & $23 \pm 17$ & 0.983 \\
\hline Nitrogen free extract & $443 \pm 77$ & $435 \pm 61$ & $442 \pm 71$ & $441 \pm 69$ & 0.887 \\
\hline \multicolumn{6}{|l|}{ Ration B (g/h/d) } \\
\hline Dry matter & $834 \pm 194$ & $976 \pm 164$ & $979 \pm 136$ & $891 \pm 185$ & 0.238 \\
\hline Ash & $88 \pm 34$ & $103 \pm 44$ & $102 \pm 39$ & $94 \pm 38$ & 0.590 \\
\hline Crude protein & $152 \pm 30$ & $180 \pm 38$ & $182 \pm 47$ & $163 \pm 36$ & 0.204 \\
\hline Crude fiber & $309 \pm 95$ & $359 \pm 86$ & $360 \pm 82$ & $329 \pm 90$ & 0.410 \\
\hline Ether extract & $6 \pm \quad 2$ & $7 \pm \quad 2$ & $7 \pm \quad 2$ & $7 \pm \quad 2$ & 0.516 \\
\hline Nitrogen free extract & $280 \pm 71$ & $329 \pm 74$ & $329 \pm 62$ & $299 \pm 71$ & 0.299 \\
\hline \multicolumn{6}{|l|}{ Ration C (g/h/d) } \\
\hline Dry matter & $992 \pm 295$ & $1,248 \pm 401$ & $1,208 \pm 344$ & $1,086 \pm 329$ & 0.247 \\
\hline Ash & $131 \pm 40$ & $166 \pm 57$ & $161 \pm 50$ & $144 \pm 46$ & 0.261 \\
\hline Crude protein & $169 \pm 70$ & $218 \pm 107$ & $211 \pm 96$ & $187 \pm 81$ & 0.386 \\
\hline Crude fiber & $370 \pm 100$ & $458 \pm 101$ & $444 \pm 89$ & $402 \pm 101$ & 0.194 \\
\hline Ether extract & $28 \pm 14$ & $35 \pm 21$ & $34 \pm 18$ & $30 \pm 16$ & 0.487 \\
\hline Nitrogen free extract & $294 \pm 104$ & $372 \pm 149$ & $360 \pm 117$ & $323 \pm 117$ & 0.331 \\
\hline
\end{tabular}

2000). Therefore, to improve the productivity of the deer, it is necessary to offer a high protein ration (Sookhareea \& Dryden, 2004).

Ration A indicated high dry matter and fiber intake in all age classes of the deer. However, in most animal, high dry matter intake is associated with low fiber intake. Sambar deer (Cervus unicolor) indicated a high preference to low fiber diets. High fiber diet reduced dry matter intake (Afzalani et al., 2008), since fiber component of ingested feed increases ruminal retention time. Fibrous feeds indicate high bulkyness. High intake of fibrous feed creates high tention to the rumen wall and stimulate satietary effect and decreases dry matter intake (Toharmat et al., 2006). Low dry matter intake was highly corellated with low nutrien digestibily and the high rate of feed particles passage, which were mostly dictated by the level of fiber intake (Tafaj et al., 2005). A high fiber intake in Timor deer indicated that the deer were addapted and tolerant to the high fiber diet.

\section{Minerals Intake}

Intake of macro mineral in deer at different age is presented in Table 4. Phosphor and S intake of deer were higher in $\mathrm{A}$ ration than that in $\mathrm{B}$ and $\mathrm{C}$ rations. On the other hand, $\mathrm{Ca}$ and $\mathrm{Mg}$ intake were similar in all rations. Mineral intake was not affected by deer age. Sufficiency of $\mathrm{P}, \mathrm{Ca}, \mathrm{Mg}$, and $\mathrm{S}$ intake, allowed the normal growth of velvet antler and tissue. Some grasses indicated low content of macro minerals. To meet the requirement of esential macro minerals, the dietary supplementation of $\mathrm{P}$ and $\mathrm{Ca}$ was likely necessary in deer offered grasses as a sole ration.

Intake of macro mineral of deer at different age classes in each diet was not different $(\mathrm{P}<0.05)$. However, the macro mineral intake differed among diets, which was the highest in ration $\mathrm{A}$. Intake of $\mathrm{Ca}, \mathrm{P}, \mathrm{Mg}$, and $\mathrm{S}$ was $14.6,5.7,5.02$, and $7.56 \mathrm{~g} / \mathrm{kg}$ body weight. Intake of the $\mathrm{Ca}, \mathrm{Mg}$ and $\mathrm{S}$ met the requirement of deer, but the intake of $\mathrm{P}$ was lower than that required.

McDonald et al. (2011) reported that $\mathrm{Ca}, \mathrm{P}, \mathrm{Mg}$, and $S$ content of the deer body was $15,10,0.4$, and $1.5 \mathrm{~g} / \mathrm{kg}$ body weight, respectively. In adult animal, Ca deficiency resulted in osteomalacia indicated by reduction of bone strength. On the other hand, deficiency of $\mathrm{P}$ resulted in abnormal appetite indicated by beating foreign material around cage (McDonald et al., 2011). Nowicka et al. (2006) reported that mineralization of velvet and head bone was affected by age and environmental condition of the animal. Calcium content of velvet was $133.96 \mathrm{mg} /$ $\mathrm{g}$, which was higher than the Ca content of head bone of $123.79 \mathrm{mg} / \mathrm{g}$, in vice versa for $\mathrm{P}$, which was $83.58 \mathrm{mg} / \mathrm{g}$ velvet and $84.62 \mathrm{mg} / \mathrm{g}$ of head bone. 
Table 4. Mean of daily macro mineral intake of Timor deer in different age class in a captive area $(\mathrm{g} / \mathrm{d})$

\begin{tabular}{|c|c|c|c|c|c|}
\hline Age class, year & 3 & 6 & 9 & & \\
\hline Body weight, kg & 55.63 & 62.4 & 60.6 & Mean & Signif. \\
\hline $\mathrm{n}$ & 3 & 1 & 1 & & \\
\hline \multicolumn{6}{|l|}{ Ration A } \\
\hline Calcium & $14.60 \pm 0.30$ & $14.60 \pm 0.50$ & $14.60 \pm 0.70$ & $14.60 \pm 0.40$ & 0.965 \\
\hline Phosphor & $5.70 \pm 0.10$ & $5.70 \pm 0.20$ & $5.70 \pm 0.10$ & $5.70 \pm 0.10$ & 0.514 \\
\hline Magnesium & $5.06 \pm 0.11$ & $4.95 \pm 0.21$ & $5.05 \pm 0.16$ & $5.02 \pm 0.15$ & 0.462 \\
\hline Sulphur & $7.53 \pm 0.06$ & $7.57 \pm 0.10$ & $7.58 \pm 0.10$ & $7.56 \pm 0.08$ & 0.533 \\
\hline \multicolumn{6}{|l|}{ Ration B } \\
\hline Calcium & $8.10 \pm 1.00$ & $9.50 \pm 1.70$ & $9.60 \pm 1.30$ & $9.04 \pm 1.40$ & 0.244 \\
\hline Phosphor & $2.10 \pm 0.30$ & $2.50 \pm 0.50$ & $2.50 \pm 0.40$ & $2.30 \pm 0.40$ & 0.279 \\
\hline Magnesium & $2.99 \pm 0.33$ & $3.41 \pm 0.58$ & $3.50 \pm 0.44$ & $3.32 \pm 0.47$ & 0.236 \\
\hline Sulphur & $2.23 \pm 0.24$ & $2.61 \pm 0.61$ & $2.68 \pm 0.43$ & $2.51 \pm 0.44$ & 0.285 \\
\hline \multicolumn{6}{|l|}{ Ration C } \\
\hline Calcium & $9.70 \pm 2.70$ & $12.60 \pm 1.00$ & $12.20 \pm 1.40$ & $11.50 \pm 2.10$ & 0.107 \\
\hline Phosphor & $3.90 \pm 1.00$ & $5.10 \pm 0.40$ & $4.90 \pm 0.60$ & $4.60 \pm 0.80$ & 0.108 \\
\hline Magnesium & $4.04 \pm 1.11$ & $5.64 \pm 0.45$ & $5.10 \pm 0.64$ & $4.81 \pm 0.89$ & 0.108 \\
\hline Sulphur & $3.17 \pm 0.87$ & $4.16 \pm 0.39$ & $3.98 \pm 0.53$ & $3.77 \pm 0.71$ & 0.113 \\
\hline
\end{tabular}

The total of $70 \%$ body $\mathrm{Mg}$ is deposited in the skeleton and the remainder is deposited in soft tissue and body fluid (McDonald et al., 2011). Magnesium intake in the present study was higher than that required, since some grasses, such as Coixlacryma and Scrophia sp. were high in Mg. However, to increase the intake of $\mathrm{Ca}$ and $P$ in deer offered grass based diet, dietary supplementation of these minerals is necessary, to reduce the excessive mobilization of the mineral from the bone.

Intake of $\mathrm{P}$ and Ca was $0.6-0.7$ and $0.3-0.4 \mathrm{mg} / \mathrm{kg}$ body weight of the deer, respectively. The values was lower than $\mathrm{P}$ and $\mathrm{Ca}$ required by the deer. McDonald et al (2011) reported that the macro minerals in the body tissue of deer were 15, 10, and $0.4 \mathrm{~g} / \mathrm{kg}$ for $\mathrm{Ca}, \mathrm{P}$, and $\mathrm{Mg}$. Supplementation of $\mathrm{Ca}$ and $\mathrm{P}$ to meet the normal growth may minimize resorption of these minerals at the rate of $25 \mathrm{~g} / \mathrm{d}$ from their bone, during the peak growth of velvet antler. Nowicka et al. (2006) reported that the mineralization of velvet antler and head skeleton in the deer was influenced by age and their environment condition. Calcium content of velvet antler and head skeleton was is 133.96 and $123.79 \mathrm{mg} / \mathrm{g}$, respectively. Velvet antler and head skeleton of the deer contained Ca and $\mathrm{P}$ of 84.62 and $83.58 \mathrm{mg} / \mathrm{g}$, respectively.

Intake of $\mathrm{Fe}, \mathrm{Mn}, \mathrm{Cu}$, and $\mathrm{Zn}$ in deer at different age is presented in Table 5. There was no different in micro minerals intake in deer offered different rations. However, the micro mineral intake of the deer in the same age class differed significantly among rations. High intake of micro minerals was observed in the deer offered ration $\mathrm{A}$.

Micro mineral intake of deer was higher when the deer were offered ration A. Iron (Fe), Mn, $\mathrm{Cu}$ and $\mathrm{Zn}$ content in body tissue of the deer was 20-80, 0.2-0.6 $\mathrm{mg} / \mathrm{kg}, 1-5$, and $10-50 \mathrm{mg} / \mathrm{kg}$, respectively (McDonald et al.2011). Intake of the micro minerals of the deer fed grasses based diets was likely met the requirement.

\section{Velvet Antler Characteristic}

Mean of body morphometry of Timor deer in different age class kept in a captive area is presented in Table 6. Length of velvet antler of the Timor deer was clasified into E class. Mean of velvet antler diameter of Timor deer was $28.18 \pm 4.36 \mathrm{~mm}$. Handarini (2006) reported that main part of velvet had diameter of $39.03 \pm 6.86$ $\mathrm{mm}$. The different in diameter of velvet antler might be associated with the time of harvesting and ingested nutrients. Diemeter of the velvet antler was not in the range values for grading velvet antler for red deer $(C$. elaphus). Clasification of velvet antler for red deer was based on its length and diameter at 55-60 d old, whereas the length and diameter of velvel antler is seted in the range of $11-16$ and $30-40 \mathrm{~cm}$, respectively. Timor rusa has different physical characteristic with red deer, Timor deer has smaller body size and shorter body length then the red deer.

At 3, 6, and 9 yr old, Timor deer produces 0.5, 0.6, and $0.7 \mathrm{~kg}$ velvet antler, respectively. Dradjat (2000) reported that Timor x Sambar cross breed deer produced $1.34 \pm 0.23 \mathrm{~kg}$ of velvet antler. Sambar deer kept in a captive area produced velvet antler of $0.69 \mathrm{~kg} / \mathrm{pair}$ which had length of 20.49-21.37 cm (Jamal et al., 2005). Although, Sambar deer had higher body weight, the deer produced lower weight and shorter velvet antler than that of Timor deer when they kept in a captive area. Cross breed Sambar x Timor deer produced havier and longer velvet antler than both breeds. The result indicated that clasification of velvet antler should be based on the type of deer. 
Weight and diameter of velvet antler harvested on day 60 from Timor deer had high corelation with the age and girt diameter of the deer. The regression equetion of weight and age was expressed as follows: $Y=0.4+0.03$ $\mathrm{X} ; \mathrm{r}^{2}=99 \% ; \mathrm{P}<0.05, \mathrm{Y}=$ weight of velvet antler and $\mathrm{X}=$ age. The regression equetion of length and girt diameter was expressed as follows: $\mathrm{Y}=5.7+0.31 \mathrm{X}, \mathrm{r}^{2}=99 \%, \mathrm{P}<0.05, \mathrm{Y}=$ length of velvet antler and $X=$ girt diameter. Handarini (2006) reported that the velvet antler indicated a maksi- mum length at a given age, that followed the sigmoid curve.

\section{Minerals and Amino Acids Content of Velvet Antler}

Macro and micro minerals content of velvet antler harvested on day 36, from Timor deer in different age classes are presented in Table 7 and 8. Macro and micro mineral content of velvet antler harvested on day 36

Table 5. Mean of daily micro mineral intake of Timor deer in different age class in a captive area

\begin{tabular}{|c|c|c|c|c|c|}
\hline Age class (yr) & 3 & 6 & 9 & \multirow{3}{*}{ Mean } & \multirow{3}{*}{ Signif. } \\
\hline Body weight, kg & 55.63 & 62.4 & 60.6 & & \\
\hline $\mathrm{n}$ & 3 & 1 & 1 & & \\
\hline \multicolumn{6}{|l|}{ Ration A } \\
\hline $\mathrm{Fe}, \mathrm{g} / \mathrm{d}$ & $0.920 \pm 0.020$ & $0.900 \pm 0.020$ & $0.910 \pm 0.030$ & $0.910 \pm 0.030$ & 0.507 \\
\hline $\mathrm{Mn}, \mathrm{g} / \mathrm{d}$ & $0.340 \pm 0.010$ & $0.340 \pm 0.010$ & $0.340 \pm 0.020$ & $0.340 \pm 0.010$ & 0.712 \\
\hline $\mathrm{Cu}, \mathrm{g} / \mathrm{d}\left(\mathrm{x} 10^{-2}\right)$ & $0.990 \pm 0.020$ & $0.980 \pm 0.020$ & $0.990 \pm 0.030$ & $0.990 \pm 0.020$ & 0.786 \\
\hline $\mathrm{Zn}, \mathrm{g} / \mathrm{d}$ & $0.074 \pm 0.001$ & $0.072 \pm 0.002$ & $0.073 \pm 0.002$ & $0.073 \pm 0.002$ & 0.417 \\
\hline \multicolumn{6}{|l|}{ Ration B } \\
\hline $\mathrm{Fe}, \mathrm{g} / \mathrm{d}$ & $0.510 \pm 0.050$ & $0.590 \pm 0.090$ & $0.580 \pm 0.080$ & $0.560 \pm 0.080$ & 0.307 \\
\hline $\mathrm{Mn}, \mathrm{g} / \mathrm{d}$ & $0.180 \pm 0.020$ & $0.210 \pm 0.020$ & $0.210 \pm 0.020$ & $0.200 \pm 0.030$ & 0.139 \\
\hline $\mathrm{Cu}, \mathrm{g} / \mathrm{d}\left(\mathrm{x} 10^{-2}\right)$ & $0.690 \pm 0.100$ & $0.820 \pm 0.100$ & $0.840 \pm 0.130$ & $0.780 \pm 0.140$ & 0.259 \\
\hline $\mathrm{Zn}, \mathrm{g} / \mathrm{d}$ & $0.025 \pm 0.003$ & $0.030 \pm 0.005$ & $0.030 \pm 0.005$ & $0.028 \pm 0.005$ & 0.293 \\
\hline \multicolumn{6}{|l|}{ Ration C } \\
\hline $\mathrm{Fe}, \mathrm{g} / \mathrm{d}$ & $0.450 \pm 0.080$ & $0.530 \pm 0.070$ & $0.520 \pm 0.070$ & $0.500 \pm 0.070$ & 0.173 \\
\hline $\mathrm{Mn}, \mathrm{g} / \mathrm{d}$ & $0.290 \pm 0.050$ & $0.350 \pm 0.050$ & $0.350 \pm 0.030$ & $0.330 \pm 0.040$ & 0.128 \\
\hline $\mathrm{Cu}, \mathrm{g} / \mathrm{d}\left(\times 10^{-2}\right)$ & $1.220 \pm 0.400$ & $1.670 \pm 0.360$ & $1.600 \pm 0.210$ & $1.500 \pm 0.320$ & 0.099 \\
\hline $\mathrm{Zn}, \mathrm{g} / \mathrm{d}$ & $0.047 \pm 0.012$ & $0.059 \pm 0.009$ & $0.058 \pm 0.006$ & $0.055 \pm 0.008$ & 0.109 \\
\hline
\end{tabular}

Table 6. Mean of body morphometry of Timor deer in different age class kept in a captive area

\begin{tabular}{cccccccccc}
\hline \multirow{2}{*}{$\begin{array}{c}\text { Age } \\
(\mathrm{yr})\end{array}$} & $\begin{array}{c}\text { Velvet } \\
\text { weight } \\
(\mathrm{kg})\end{array}$ & $\begin{array}{c}\text { Velvet } \\
\text { length } \\
(\mathrm{cm})\end{array}$ & $\begin{array}{c}\text { Branch } \\
\text { length } \\
(\mathrm{cm})\end{array}$ & $\begin{array}{c}\text { Velvet } \\
\text { diameter } \\
(\mathrm{mm})\end{array}$ & $\begin{array}{c}\text { Velvet age } \\
(\mathrm{d})\end{array}$ & $\begin{array}{c}\text { Body } \\
\text { weight } \\
(\mathrm{kg})\end{array}$ & $\begin{array}{c}\text { Body } \\
\text { length } \\
(\mathrm{cm})\end{array}$ & $\begin{array}{c}\text { Heart girth } \\
(\mathrm{cm})\end{array}$ & $\begin{array}{c}\text { Body } \\
\text { height } \\
(\mathrm{cm})\end{array}$ \\
\hline 3 & 0.5 & 26 & 13 & 26 & 60 & 55 & 78 & 66 & 76 \\
6 & 0.6 & 31 & 14 & 30 & 60 & 62 & 88 & 83 & 83 \\
9 & 0.7 & 32 & 15 & 34 & 65 & 61 & 84 & 86 & 84 \\
\hline
\end{tabular}

Table 7. Macro mineral content of velvet antler harvested on day 60, from Timor deer in different age classes

\begin{tabular}{|c|c|c|c|c|c|c|}
\hline \multirow{2}{*}{$\begin{array}{l}\text { Age class } \\
\quad(\mathrm{yr})\end{array}$} & \multirow{2}{*}{$\begin{array}{l}\text { Body weight } \\
\qquad(\mathrm{kg})\end{array}$} & \multirow{2}{*}{$\mathrm{n}$} & \multicolumn{4}{|c|}{ Macro minerals (g/kg DM) } \\
\hline & & & $\mathrm{P}$ & $\mathrm{Ca}$ & $\mathrm{Mg}$ & S \\
\hline 3 & 55.63 & 3 & $49.96 \pm 1.60^{c}$ & $25.76 \pm 0.83^{c}$ & $1.03 \pm 0.03^{c}$ & $1.08 \pm 0.03^{c}$ \\
\hline 6 & 62.40 & 1 & $57.63 \pm 0.64^{\mathrm{b}}$ & $29.72 \pm 0.32^{\mathrm{b}}$ & $1.19 \pm 0.01^{\mathrm{b}}$ & $1.24 \pm 0.01^{\mathrm{b}}$ \\
\hline \multirow[t]{2}{*}{9} & 60.60 & 1 & $67.62 \pm 0.92^{\mathrm{a}}$ & $34.87 \pm 0.47^{\mathrm{a}}$ & $1.40 \pm 0.02^{\mathrm{a}}$ & $1.46 \pm 0.02^{\mathrm{a}}$ \\
\hline & Mean & & $55.03 \pm 7.32$ & $28.38 \pm 3.78$ & $1.14 \pm 0.15$ & $1.19 \pm 0.16$ \\
\hline
\end{tabular}

Note: Means in the same column with different superscript differ significantly $(\mathrm{P}<0.05)$. 
from timor deer in different age class. Macro and micro minerals content, of velvet antler, were higher in the older deer than those in younger deer.

Quality of velvet antler is based upon its protein content indicating by amino acids composition. Protein content of velvet antler was negatively correlated with the Ca content. The increase in Ca content, which is inline with the growth of velvet antler, results in a decrease in protein content and therefore its total amino acids, uronic acid, and sialic acid content decrease. On the other hand, the increase in Ca is accociated with the increase in ash and collagen content of the velvet, and therefor reduces the quality of velvet (Jeon et al., 2009).

Amino acids content of velvet antler harvested on day 36 from Timor deer in different age classes is presented in Table 9. There was no different in essential amino acid content of velvet antler among age classes of the deer. Most essential amino acids in the velvet antler were likely not affected by the intake of protein or other nutrients. However the nutrient intake might increase the total weight of velvet antler, therefore they increaed the total of nutrients including amino acids as components of the velvet antler. Aspartic acid, glutamic acid, and prolin content in velvet antler were high in the older deer. The older deer indicated higher metabolism activity in synthesizing non-essential amino acids and deposited the amino acids in the velvet antler.

\section{CONCLUSION}

Timor deers indicate different preference to the available species of grasses and has the highest preference to ration composed of P. purpureum, C. benghalensis, $H$. horsfieldii, and $S$. caudatum. High intake of grasses increase body weight of the deer but it does not change the composition of nutrient in the velvet antler of the

Table 8. Micro mineral content of velvet antler harvested on day 60 from Timor deer in different age class

\begin{tabular}{|c|c|c|c|c|c|c|}
\hline \multirow{2}{*}{$\begin{array}{l}\text { Age class } \\
\quad(\mathrm{yr})\end{array}$} & \multirow{2}{*}{$\begin{array}{l}\text { Body weight } \\
(\mathrm{kg})\end{array}$} & \multirow{2}{*}{$\mathrm{n}$} & \multicolumn{4}{|c|}{ Micro minerals (mg/kg DM) } \\
\hline & & & $\mathrm{Fe}$ & Mn & $\mathrm{Cu}$ & $\mathrm{Zn}$ \\
\hline 3 & 55.63 & 3 & $260.35 \pm 8.34^{c}$ & $2.25 \pm 0.07^{c}$ & $58.35 \pm 1.87^{c}$ & $130.17 \pm 4.17$ \\
\hline 6 & 62.40 & 1 & $300.33 \pm 3.29^{b}$ & $2.59 \pm 0.03^{b}$ & $67.31 \pm 0.73^{\mathrm{b}}$ & $150.16 \pm 1.64^{\mathrm{b}}$ \\
\hline \multirow[t]{2}{*}{9} & 60.60 & 1 & $352.37 \pm 4.78^{\mathrm{a}}$ & $3.04 \pm 0.05^{\mathrm{a}}$ & $78.98 \pm 1.07^{\mathrm{a}}$ & $176.19 \pm 2.38^{a}$ \\
\hline & Mean & & $286.75 \pm 38.14$ & $2.47 \pm 0.33$ & $64.27 \pm 8.55$ & $143.37 \pm 19.07$ \\
\hline
\end{tabular}

Note: Means in the same column with different superscript differ significantly $(\mathrm{P}<0.05)$.

Table 9. Amino acids content of velvet antler harvested from Timor deer in different age class (mg/kg DM)

\begin{tabular}{|c|c|c|c|c|}
\hline Age class (yr) & 3 & 6 & 9 & \multirow{3}{*}{ Mean } \\
\hline \multirow{2}{*}{$\begin{array}{l}\text { Body weight, } \mathrm{kg} \\
\mathrm{n}\end{array}$} & 55.63 & 62.4 & 60.6 & \\
\hline & 3 & 1 & 1 & \\
\hline Asp & $11.25 \pm 3.01^{\mathrm{c}}$ & $19.23 \pm 1.73^{\mathrm{b}}$ & $25.55 \pm 2.47^{\mathrm{a}}$ & $15.70 \pm 6.60$ \\
\hline Glu & $15.97 \pm 3.46^{c}$ & $35.63 \pm 1.46^{\mathrm{b}}$ & $43.39 \pm 3.39^{\mathrm{a}}$ & $25.38 \pm 12.75$ \\
\hline Ser & $8.03 \pm 3.36$ & $5.67 \pm 0.55$ & $7.91 \pm 0.40$ & $7.53 \pm 2.70$ \\
\hline Gly & $8.85 \pm 4.89$ & $6.66 \pm 0.68$ & $10.31 \pm 2.21$ & $8.70 \pm 3.93$ \\
\hline $\left.\mathrm{His}^{*}\right)$ & $8.73 \pm 2.92$ & $5.24 \pm 0.78$ & $7.64 \pm 0.64$ & $7.81 \pm 2.62$ \\
\hline $\left.\operatorname{Arg}^{*}\right)$ & $7.81 \pm 2.92$ & $5.81 \pm 1.04$ & $10.56 \pm 0.18$ & $7.96 \pm 2.72$ \\
\hline Thr*) & $7.25 \pm 4.32$ & $5.79 \pm 0.59$ & $8.56 \pm 0.03$ & $7.22 \pm 3.36$ \\
\hline Ala & $7.31 \pm 4.84$ & $4.70 \pm 0.11$ & $6.36 \pm 0.62$ & $6.60 \pm 3.77$ \\
\hline Pro & $6.40 \pm 1.22^{c}$ & $9.68 \pm 0.45^{b}$ & $13.46 \pm 0.86^{\mathrm{a}}$ & $8.47 \pm 3.10$ \\
\hline Tyr & $7.36 \pm 4.71$ & $5.16 \pm 0.17$ & $7.00 \pm 0.35$ & $6.85 \pm 3.63$ \\
\hline $\left.\mathrm{Val}^{*}\right)$ & $7.68 \pm 3.44$ & $4.32 \pm 0.30$ & $6.20 \pm 0.10$ & $6.71 \pm 2.92$ \\
\hline $\left.\mathrm{Met}^{*}\right)$ & $8.39 \pm 4.02$ & $4.89 \pm 0.25$ & $5.97 \pm 0.47$ & $7.21 \pm 3.38$ \\
\hline Sis & $5.90 \pm 2.32$ & $3.87 \pm 0.17$ & $4.75 \pm 0.18$ & $5.26 \pm 1.94$ \\
\hline $\left.\mathrm{Ile}^{*}\right)$ & $7.10 \pm 4.71$ & $9.47 \pm 0.32$ & $11.86 \pm 1.26$ & $8.52 \pm 4.06$ \\
\hline Leu $\left.^{*}\right)$ & $9.85 \pm 4.09$ & $10.50 \pm 0.34$ & $12.99 \pm 1.44$ & $10.61 \pm 3.34$ \\
\hline Phe $^{*}$ ) & $7.65 \pm 3.24$ & $5.81 \pm 0.45$ & $6.78 \pm 0.51$ & $7.10 \pm 2.55$ \\
\hline Lys*) & $9.08 \pm 3.72$ & $6.78 \pm 0.51$ & $7.39 \pm 0.74$ & $8.28 \pm 2.98$ \\
\hline
\end{tabular}

Note: ${ }^{*}$ Essential amino acids 
deer. Age of the deer is the determinant of the weight of velvet antler and the hearth girth is the determinant factor of length of the velvet antler. Older deers have higher non essential amino acids. However, age and nutrient intake have no effect on amino acids composition of velvet antler.

\section{REFERENCES}

Afzalani, R., A Muthalib, \& E. Musnandar. 2008. Preferensi pakan, tingkah laku makan dan kebutuhan nutrien rusa sambar (Cervus unicolor) dalam usaha penangkaran di Provinsi Jambi. Med. Pet. 31:114-121

Babayemi, O. J, M. A. Bamikole, \& A. B. Omojola. 2006. Evaluation of nutritive value and free choise intake of two aquatic wees (Nephrolepis besrrata and Spirodela polyrhiza) by west African dwarf goats. Tropical and subtropical Agroecosystems 6:15-21.

Ceacero, F., T. Landete-Castillejos, A. J. Garcia, J. A. Estevez, \& L. Gallego. 2010. Can Iberian red deer (Cervus elaphus hispanicus) discriminate among essential minerals in their diet?. Br. J. Nutr. 103:617-626. http://dx.doi.org/10.1017/ S0007114509992091

Demarais, S. 2002. Managing for Antler Production: Understanding Age, Nutrition, and Genetic Influences. Research Advance FWRC 7

Dradjat, A. S. 2000. Produksi ranggah muda pada persilangan rusa timorensis (Cervus timorensis) dan rusa sambar (Cervus unicolor). Med. Pet. 23: 36-39

Estevez, J. A., T. Landete-Castilajos, A. Martinez, A. J. Garcia, F. Ceacero, E. Gaspar-Lopez, A. Calatayud, \& L. Gallego. 2008. Antler mineral composition of Iberian red deer Cervus hispanicus is related to mineral profile of diet. Acta Theriologica 54: 235-242. http://dx.doi.org/10.4098/j.at.00017051.070.2008

Farid, M. F. A., H. S. Khamis, \& E. Y. A. E. 2006. Competent feeding management a requirement for profi table sheep production, experimental evidence in Egipt. Egyptian Journal of Sheep, Goat and Anim. Sci. 1:117-133.

Gibbs, D. 2006. Antler Development in White-tailed Deer. Tennessee Wildlife Rosources Agency. September 1, 2006.

Handarini, R. 2006. Pola dan siklus pertumbuhan ranggah rusa timor jantan (Cervus timorensis). J. Agribisnis Peternakan 2: 28-35

Hedges, S., J.W. Duckworth, R. J. Timmins, G. Semiadi, \& A. Priyono. 2008. Rusa timorensis. In: IUCN 2012. IUCN Red List of Threatened Species. Version 2012.2. <www.iucnredlist.org >. Downloaded on 24 May 2013

Jamal, Y., G. L. Semiadi, \& R. T. P. Nugraha. 2005. Kualitas produk ranggah muda rusa sambar (Cervus unicolor) tangkaran. Biologi 4: 325 - 335.

Jeon, B. T., M. H. Kim, S. M. Lee, \& S. H. Moon. 2006a. Effect of dietary protein on dry matter intake, and production and chemical composition of velvet antler in spotted deer fed forest by-product silage. Asian-Aust. J. Anim.Sci. 19: 17371741

Jeon, B. T., M. H. Kim, S. M. Lee, D. G. Thomas, \& S. H. Moon. 2006b. Changes of chemical composition in blood serum during the antler growth period in spotted deer (Cervus nippon). Asian-Aust. J. Anim. Sci. 19: 1298-1304.

Jeon, B. T., S.H. Cheong, D. H. Kim, J. H. Park, P. J. Park, S. H. Sung, D. G. Thomas, K. H Kim, \& S. H Moon. 2011. Effect of antler development stage on chemical of velvet antler in Elk (Cervus elaphus canadensis). Asian-Aust. J. Anim.Sci 24:1303-1313. http://dx.doi.org/10.5713/ajas.2011.10412

Jeon, B., S. Kim, S. Lee, P. Park, S. Sung, J. Kim, \& S. Moon. 2009. Effect of antler growth period on the chemical composition of velvet antler in sika deer (Cervus nippon). Mammalian Biology 74:374-378. http://dx.doi.org/10.1016/ j.mambio.2008.07.005

Kawtikwar, P. S., D. A. Bhagwat, \& D. M. Sakarkar. 2010. Deer antler-Traditional use and future perspectives. Indian Journal of Traditional Knowledge 9: 245-251.

Kilgo, J. C. \& R. F. Labisky. 1995. Nutritional quality of three major deer forages in pine flatwoods of northern Florida. Florida Scientist 58:320-326

Lee, S. R, B. T. Jeon, S. J. Kim, M. H. Kim, S. M. Lee, \& S. H. Moon. 2007. Effect of antler development stage on fatty acid, vitamin and GAGs contents of velvet antler in spotted deer (Cervus nippon). Asian-Aust.J Anim.Sci. 20: 15461550.

Luna, R. S, A. Duarte, \& F. W Weckerly. 2013. Influence of body size on dietary nutrition of white-tailed deer Odocoileus virginianus. Journal of Fish and Wildlife Management 4:43-62. doi: 10.3996/092012-JFWM-085

McDonald, P., R. A. Edwards, J. F. D. Greenhalgh, C. A. Morgan, L. A Sinclair, R. G. Wilkinson. 2011. Animal Nutrition. Seventh edition. Prentice Hall, New York.

Nowicka, W., Z. Machoy, I. Gutowska, I. Nocen, S. Piotrowska, \& D. Chlubek. 2006. Contents of calcium, magnesium, and phosphorus in antlers and cranial bones of the European red deer (Cervus elaphus) from different region. Polish J. Environ. Stud.15: 297-301.

Pattiselanno, F. 2003. Deer (Cervidae : Artiodactyla: Mammalia) wildlife potential with future expectation. Tigerpaper 30: 13-16.

Rodriguez, A., S. Bodas, B. Fernandes, O. L. Campos, A. R. Manteoon, \& F. J. Giraldez. 2007. Feed intake and performance of growing lambs raised on concenrate- based diets under cafetaria feeding sustem. J. Anim 1:459-466. http:// dx.doi.org/10.1017/S1751731107683803

Scmidt, K. T., A. Stien, A. S. Albon, \& F. E. Guinness. 2001. Antler length of yearling red deer is determined by population density, weather and early life-history. Oecologia 127: 191-197. http://dx.doi.org/10.1007/s004420000583

Shin H. T., R. J. Hudson, X. H. Gao, \& J. M. Suttie. 2000. Nutritional requirements and management strategies for farmed deer. Asian-Aus. J. Anim. Sci. 13: 561 - 573

Sookhareea R., \& G. McL. Dryden. 2004. Consumption and digestion of forages by male rusa (Cervus timorensisrussa) deer-the effect of castration and season. Asian-Aust. J.Anim.Sci. 17: 1098 -1106

Stewart, K. M., R. T. Bowyer, J. G. Kie, \& W. C. Kasaway. 2000. Antler size relative to body mass in Moose : Tradeoffs associated with reproduction. ALCES 36:77 - 82

Tafaj M., V. Kolaneci, B. Junck, A. Maulbetsch, H. Steingass \& W. Drochner. 2005. Influence of fiber content and concentrate level on chewing activity, ruminal digestion, digesta passage rate and nutrient digestibility in dairy cows in late lactation. Asian-Aust. J. Anim. Sci. 18:1116-1124.

Toharmat, T., E. Nursasih, R. Nazilah, N. Hotimah, T. Q. Noerzihad, N. A. Sigit \& Y. Retnani. 2006. Sifar fisik pakan kaya serat dan pengaruhnya terhadap kosumsi dan kecernaan nutrien ransum pada kambing. Med. Pet. 29: 146-154.

Tuckwell, C. 2003. Velvet Antler a summary of the literature on health benefiths. A report for the Rural Industries Research and Development Coorporation. RIRDC Publication No RIRDC Project No DIP-10A.

Walsh, V. P. \& P. R. Wilson. 2002. Chemical analgesia for velvet antler removal in deer. New Zealand Vet. J. 50:237-247. http://dx.doi.org/10.1080/00480169.2002.36319

Wirdateti \& G. Semiadi. 2007. Parameterfologi, fisiologi dan keadaan kesehatan rusa timorensis yang berada di Pulau Timor. Berkala Penelitian Hayati 3:25-30 